Forin, S.; Radebach, A. ; Steckel, J.C.; Ward, H.

\title{
The effect of industry delocalization on global energy use: A global sectoral perspective
}

Journal article | Accepted manuscript (Postprint)

This version is available at https://doi.org/10.14279/depositonce-8166

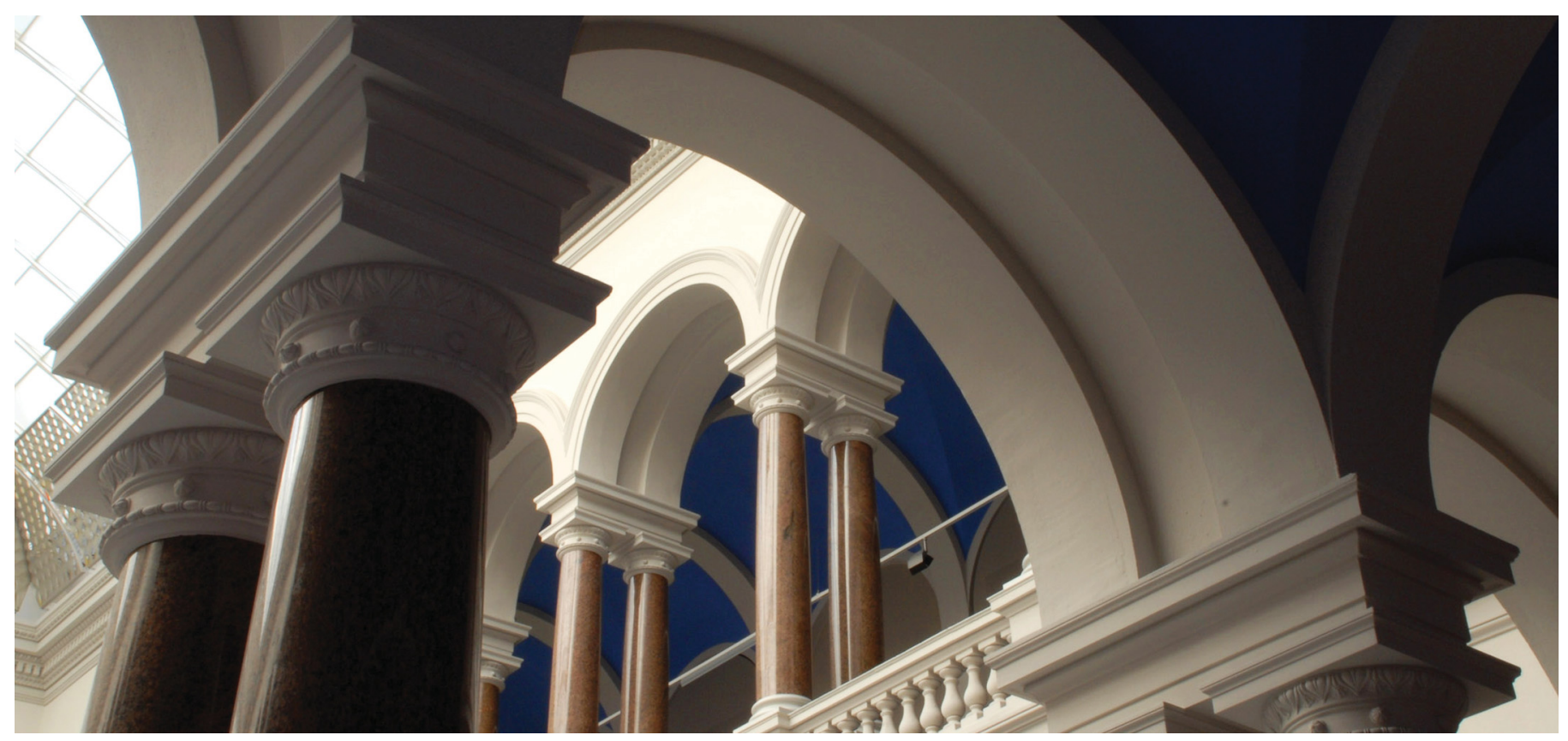

Forin, S., Radebach, A., Steckel, J. C., \& Ward, H. (2018). The effect of industry delocalization on global energy use: A global sectoral perspective. Energy Economics, 70, 233-243. https://doi.org/10.1016/j.eneco.2017.12.031 


\section{The effect of industry delocalization on global energy use: A global sectoral perspective}

\section{Introduction}

In order to achieve ambitious climate change mitigation targets as formulated in the Paris Agreement (UNFCCC, 2015), emission reductions will be necessary across all sectors of the global economy. While a first best climate policy, i.e. putting a uniform, global price on carbon would ensure that improvement potentials in economic sectors are realized in the most cost-efficient way (Weitzman, 2014), it is rather unlikely to unfold in the near future (Cramton et al., 2017; Edenhofer et al., 2015; Mackay et al., 2015).

Differing ambition levels of unilateral climate policies are feared to induce competitiveness ${ }^{1}$ losses for implementing regions (Branger and Quirion, 2015, 2014; Carbone and Rivers, 2017) and carbon leakage (see e.g., Jakob et al. 2014) through different channels (Carbone and Rivers, 2017; Dechezleprêtre and Sato, 2017). Inter alia, energy- and emission intensive trade exposed industries (EITE) (Carbone and Rivers, 2017), such as steel or aluminum could see large increases in relative production prices (Alexeeva-Talebi et al., 2012; Böhringer et al., 2012), and hence reor delocalize to regions that have less ambitious regulations and less efficient production technologies in place. Thus, a higher price of emission-intensive goods in one region could inter alia lead to increased imports from non-regulated regions (Markusen 1975, Siebert 1979), an

1 Identifying a good proxy for competitiveness is challenging (Jaffe et al., 1995). Depending on underlying studies, inter alia output, exports, employment profitability or market share have been applied (Carbone and Rivers, 2017). 
effect that potentially supports pollution havens (Cole et al., 2006; Dietzenbacher and Mukhopadhyay, 2007; Eskeland and Harrison, 2003).

As no natural counterfactual to policies exists, and effects, which are difficult to isolate, are likely heterogeneous across countries, it is difficult to explicitly evaluate policy impacts (Dechezleprêtre and Sato, 2017). Reviewing the Computable General Equilibrium (CGE) modelling literature on impacts of unilateral climate policy, Carbone and Rivers (2017) find evidence for resulting negative effects on output, exports and employment as well as carbon leakage. Nevertheless, it has been argued that depending on the rate of technological spillover and the additional technological development caused by environmental regulations, the effects of (carbon) leakage could be more than offset (Gerlagh and Kuik, 2014). Literature also acknowledged that depending on relocation barriers, domestic effects might be more relevant than effects between countries (Dechezleprêtre and Sato, 2017). For instance, the US clean air act had no impact on the cement industry, i.e. relocation of production capacities, but contributed to large health benefits (Dechezleprêtre and Sato, 2017). In the same vein, the introduction of EU ETS has not led to measurable effects for the overall economy (Dechezleprêtre and Sato, 2017). In specific cases, environmental legislation can also increase firm profits, as Branger and Quirion (2015) show for the European cement industry. Nevertheless, considering the findings of Carbone and Rivers (2017), it is conceivable that unilateral climate policy can negatively affect EITE-sectors and hence be relevant for delocalization of production capacities.

Thus far, delocalization effects have mainly been explored at aggregated economic level. Voigt et al. (2014) and Löschel et al. (2015) have decomposed the structural component of energy intensity changes into a between- and a within-country structural effect. Both studies show that while a shift towards a less energy intensive economic structure is at work in most countries, the delocalization of production (between-country structural effect) partly compensates for this development. Although drivers of changes in emissions have been investigated at sectoral level, see e.g. Branger and Quirion (2015), and predictions have been made using CGE modelling 
(Carbone and Rivers, 2017), an empirical investigation of sector-specific delocalization effects is currently missing.

In this study we aim to close this gap. We apply an advanced Logarithmic Mean Divisa Index (LMDI) decomposition methodology (Ang and Wang, 2015) to decompose energy use into value added, technological progress ${ }^{2}$ and delocalization along sectoral lines of the economy. Our analysis is based on data from the Global Trade Analysis Project (GTAP), for the years 2001, 2004, 2007 and 2011 (Dimaranan, 2006; Narayanan et al., 2015) (details in Section 2), which allows to track changes over time. We consider 57 different sectors and up to 140 regions, which we transfer into a multi-regional input-output table (Andrew and Peters, 2013). We are interested in how delocalization effected the energy consumption of global sectors. Here, we understand delocalization as a relative shift of production capacities between countries for single sectors. We assume that if production technologies in two country were different and a relative shift in production capacities occurred, the global average technology and consequently the sectoral energy consumption changed. Our analysis uses these changes and gives indirect evidence when and in which sectors delocalization occurred.

We find that the increases of value added have consistently driven energy use at the sectoral level, while technological change has continuously led to decreases in energy use in the decade 2001-2011. We find evidence for ongoing sectoral delocalization. For most sectors, delocalization increases sectoral energy use by 1-6\% per year. Delocalization effects have increased sharply in manufacturing industries that consume more than 50\% of the global energy after 2004 .

2 We use the energy intensity improvement rate to approximate technological progress. We use energy use per value added (VAD). Production chains are increasingly globalizing and fragmenting (Baldwin and Martin, 1999; Koopman et al., 2014; Timmer et al., 2014). It is hence important to adequately measure the contribution of single production steps. In contrast to output, VAD allows to reflect the significance and efficiency of a production step, i.e. how much additional value is generated from the inputs. 
Subsequently, technological progress rates within manufacturing sectors have declined (20072011).

The remainder of our paper is structured as follows. Section 2 introduces the data and the methodological foundations of the decomposition analysis. Section 3 provides the results for different sectoral aggregation levels. Section 4 discusses the results and concludes.

\section{Data and Methodology}

This section develops a framework that allows identifying delocalization between countries at sectoral level. In contrast to former studies, which have focused on energy intensity in countries or regions, we consider sectoral value added and its distribution, which is decisive considering total energy use-driven GHG emissions. We decompose sectoral energy intensity changes into delocalization and technology components, envisaging the delocalization component as being the structural effect within sectors and between countries.

\subsection{Data}

For our analysis we use the Global Trade Analysis Project (GTAP) Data Base. The GTAP Data Base can be converted into a multi-regional input-output table (Peters et al., 2011), which allows to calculate sectoral value-added. In contrast to other multi-regional input-output datasets, such as Eora (Lenzen et al., 2013) and WIOD (Timmer et al., 2015), there are no annual releases of the GTAP Data Base. However, it does provide relatively high sectoral and regional resolutions (homogeneous across regions) (Tukker and Dietzenbacher, 2013), which are crucial for investigating delocalization effects, along with data on energy use. Table 1 shows the specifications of the different GTAP Data Base releases used in this analysis. The four years of data available generate three time windows for our analysis: 2001 to 2004, 2004 to 2007 and 2007 to 2011. Wherever the regional resolution differs within a time window, the higher resolved version is aggregated into the lower resolved one (see Appendix). Each separate year in GTAP is the reference year for the monetary value (Aguiar et al., 2016). Hence, we apply price deflator factors provided by the Worldbank (Worldbank, 2017) to adjust all monetary values to 2011 USD. 


\begin{tabular}{|c|c|c|c|c|}
\hline Year & 2001 & 2004 & 2007 & 2011 \\
\hline GTAP Data Base version & 6 & \multicolumn{3}{|c|}{9} \\
\hline Documentation & $\begin{array}{c}\text { Dimaranan } \\
(2006)\end{array}$ & \multicolumn{3}{|c|}{$\begin{array}{c}\text { Narayanan et al. } \\
(2015)\end{array}$} \\
\hline number of regions & 87 & \multicolumn{3}{|c|}{140} \\
\hline number of sectors & \multicolumn{4}{|c|}{57} \\
\hline
\end{tabular}

Table 1: Overview of different GTAP versions used for each year, including their respective numbers of sectors and regions.

\subsection{Factorizing sectoral energy intensity changes with Index Decomposition Analysis}

In order to analyze the impact of delocalization on sectoral energy usage trends, we take the perspective of global production sectors, adapting and modifying the decomposition methodology by Ang and Wang (2015). Let $S$ denote the set of considered sectors and $R$ the set of considered regions in a dataset. With $E U_{s}^{t}$ we denote energy usage in the global sector $s \in S$ at time $t ; E U_{s, r}^{t}$ refers to the energy usage of sector $s$ in region $r \in R$ at time $t$. With $Y_{S}^{t}$ we denote the value-added of the global sector $s$ at time $t$, while $Y_{s, r}^{t}$ refers to the valueadded of sector $s$ in region $r$ at time $t . E U_{s}^{t}$ can thus be decomposed in the following way:

$$
\begin{aligned}
E U_{s}^{t} & =\sum_{r} \frac{Y_{s, r}^{t}}{Y_{s}^{t}} \cdot \frac{E U_{s, r}^{t}}{Y_{s, r}^{t}} \cdot Y_{s}^{t} \\
& =\sum_{r} L_{s, r}^{t} \cdot T_{s, r}^{t} \cdot Y_{s}^{t} .
\end{aligned}
$$

The first component of the right side of equation (1), $L_{S, r}^{t}=\frac{Y_{s, r}^{t}}{Y_{S}^{t}}$ is the share of the global valueadded of sector $s$ that is created in region $r$ at time $t$. This factor is novel to energy usage decomposition studies as it analyses the effect of shifts in the location of production within a global sector on energy usage. In the following we call factor $L$ the localization factor, the 
change in localization will be denoted as delocalization. The second term $T_{s, r}^{t}=\frac{E U_{S, r}^{t}}{Y_{S, r}^{t}}$ is the sectoral energy intensity of sector $s$ in region $r$ at time $t$. We call this term $T$ the technology factor. The third term $Y$ refers to the economic size of the global sector, as it considers total value added.

\subsection{Calculating the effects on energy usage change: Log Mean Divisia Index method}

The factorization of energy use, as in equation (1), represents a static perspective at a given point in time. Our approach aims to derive the temporal variation of sectoral value added, energy efficiency developments and production locations. To comply with this dynamic approach, we apply the additive Logarithmic Mean Divisia Index method (LMDI) to equation (1) (Ang and Wang, 2015).

We use the logarithmic weight function according to Ang and Wang (2015):

$$
\ell(x, y)=(x-y) / \ln \left(\frac{x}{y}\right)
$$

We obtain - analogously to Ang and Wang (2015) and Ang (2015) - the global changes in energy usage which are assigned to the factors $L, T$ and $V$ between two points in time $t_{0}$ and $t_{1}$ :

$$
\begin{gathered}
\Delta^{t_{0}, t_{1}} E U_{s}(\mathrm{~L})=\sum_{r} \ell\left(E U_{s, r}^{t_{1}}, E U_{s, r}^{t_{0}}\right) \cdot \ln \left(\frac{L_{s, r}^{t_{1}}}{L_{s, r}^{t_{0}}}\right) \\
\Delta^{t_{0}, t_{1}} E U_{s}(\mathrm{~T})=\sum_{r} \ell\left(E U_{s, r}^{t_{1}}, E U_{s, r}^{t_{0}}\right) \cdot \ln \left(\frac{T_{s, r}^{t_{1}}}{T_{s, r}^{t_{0}}}\right) \\
\Delta^{t_{0}, t_{1}} E U_{s}(\mathrm{Y})=\sum_{r} \ell\left(E U_{s, r}^{t_{1}}, E U_{s, r}^{t_{0}}\right) \cdot \ln \left(\frac{Y_{s}^{t_{1}}}{Y_{s}^{t_{0}}}\right) .
\end{gathered}
$$


The total of these three contributions give the overall absolute change in energy use of the global sector $s$ between time $t_{0}$ and $t_{1}$

$\Delta^{t_{0}, t_{1}} E U_{s}=E U_{s}^{t_{1}}-E U_{s}^{t_{0}}=\Delta^{t_{0}, t_{1}} E U_{s}(\mathrm{~L})+\Delta^{t_{0}, t_{1}} E U_{s}(\mathrm{~T})+\Delta^{t_{0}, t_{1}} E U_{s}(\mathrm{Y})$.

Outcomes of Equations (3) to (5) can be positive or negative. The following results are possible:

i) $\quad \Delta^{t_{0}, t_{1}} E U_{s}(\mathrm{~L})<0$ means that delocalization contributed to a decrease in global energy usage, i.e. a shift towards more efficient regions, while

ii) $\Delta^{t_{0}, t_{1}} E U_{s}(\mathrm{~L})>0$ shows that the delocalization factor between $t_{0}$ and $t_{1}$ contributed to increases in global energy usage, i.e. a shift towards less efficient regions.

iii) $\Delta^{t_{0}, t_{1}} E U_{S}(T)<0$ means that the technology factor contributed to a decrease in global energy usage, i.e. the global sector became more energy efficient, while

iv) $\Delta^{t_{0}, t_{1}} E U_{S}(T)>0$ shows that the technology factor between $t_{0}$ and $t_{1}$ contributed to increases in global energy usage.

v) $\Delta^{t_{0}, t_{1}} E U_{s}(\mathrm{Y})<0$ means that sectoral decline contributed to a decrease in global energy usage, while

vi) $\Delta^{t_{0}, t_{1}} E U_{s}(\mathrm{Y})>0$ means that sectoral growth lead to increases in energy usage.

To avoid misinterpretation, it is important to note that the relative delocalization effect described by a change in the localization factor $L$ is not equivalent to the usual meaning of delocalization. In fact, the data used in this paper do not allow the tracking of displacement of single organizations at micro level. What we observe are changes in the proportion of regional production of the global sector $s$ and its relationship to the sectoral energy usage. Put another 
way, the localization factor indicates whether production shares of a sector $s$ has moved, between $t_{0}$ and $t_{1}$, to more (or less) energy-intensive countries.

\section{Results}

In this section we first introduce selected stylized facts and major trends. We then continue with detailed results of our sectoral decomposition, which was introduced in detail in Section 2.

\subsection{Stylized facts and major trends}

Looking at aggregated energy use patterns across the globe, we observe a major shift of regional weights, see Figure 1. Aggregated energy consumption between 2001 and 2011 almost doubled in East Asia, replacing North America as the world's largest energy consuming region ${ }^{3}$.

In fast growing developing countries energy consumption has grown disproportionally in every macro sector ${ }^{4}$, see Figure 2. When assessing the proportion of regional consumption by macro sector, the share of consumption in "Heavy-", and "Light Manufacturing", "Utilities and Construction", "Transport and Communication" "Textiles and Wearing Apparel" and "Processed Food" in Asia has significantly increased. For all other macro sectors, shares remain relatively constant. In contrast, EU25 and North American countries have demonstrated declining energy usage shares in some macro sectors.

3 See Appendix table A3 for an overview of regions and countries.

4 Note that we separate between aggregated "macro" sectors and "micro" sectors that are further disaggregated. Table A2 gives a full list of sectors and how they are aggregated into "macro" sectors. 


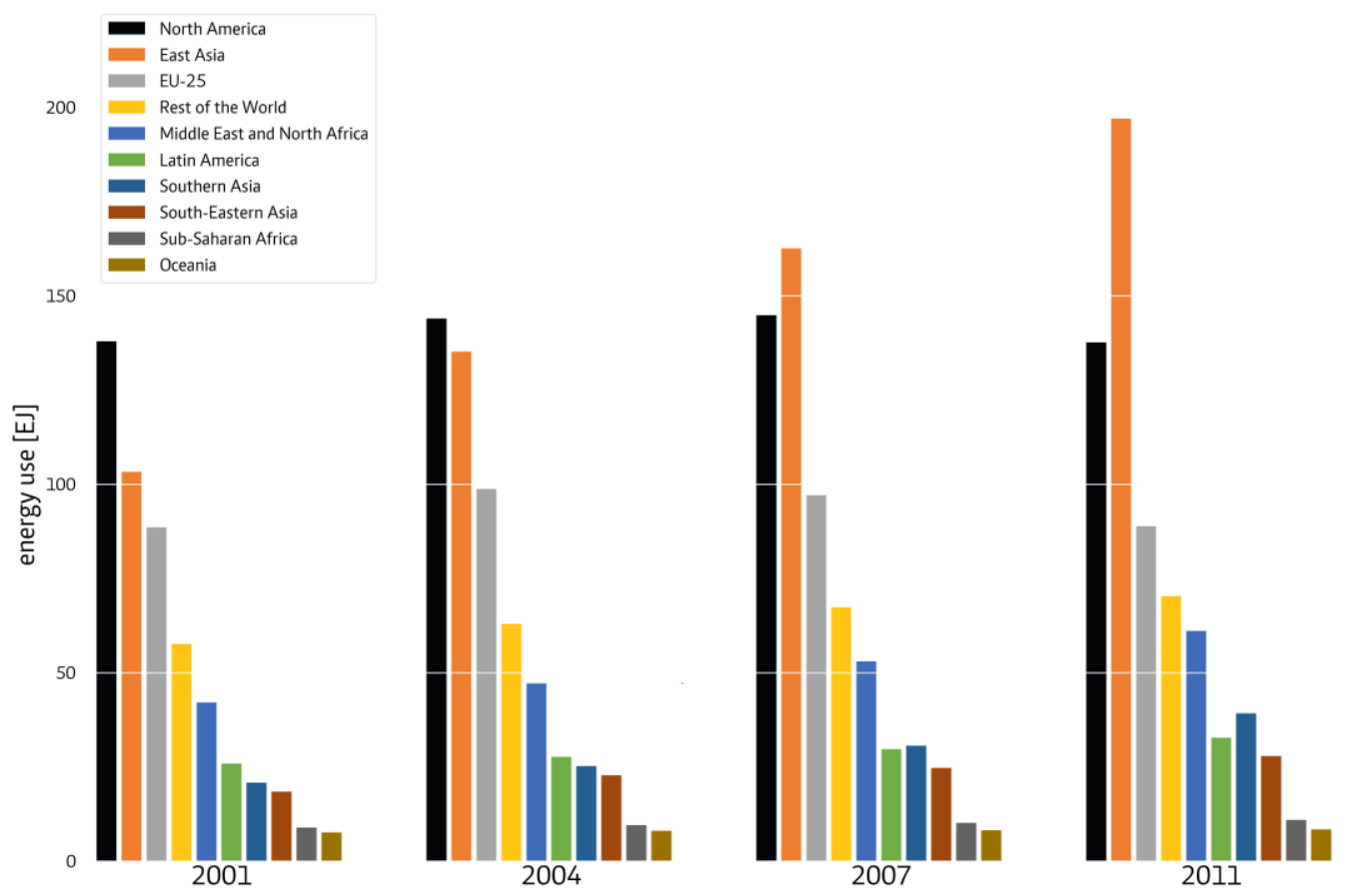

Figure 1: Primary energy usage of different world regions in Exajoules for 2001-2011.

Looking at growth in sectoral energy consumption, "Heavy Manufacturing", "Utilities and Construction" and "Transport and Communication", which are together responsible for almost $90 \%$ of global energy consumption, grew by $28 \%, 44.5 \%$ and $32.5 \%$ respectively, for the period 2001-2011. These values compare to a total growth rate of $31.9 \%$ across all sectors. The only sectors to witness a slight energy use reduction in this time period are "Textile and Wearing Apparel" and "Lifestock and Meat Products", which are the macro sectors with the lowest energy usage. The energy use in the remaining macro sectors has increased. 


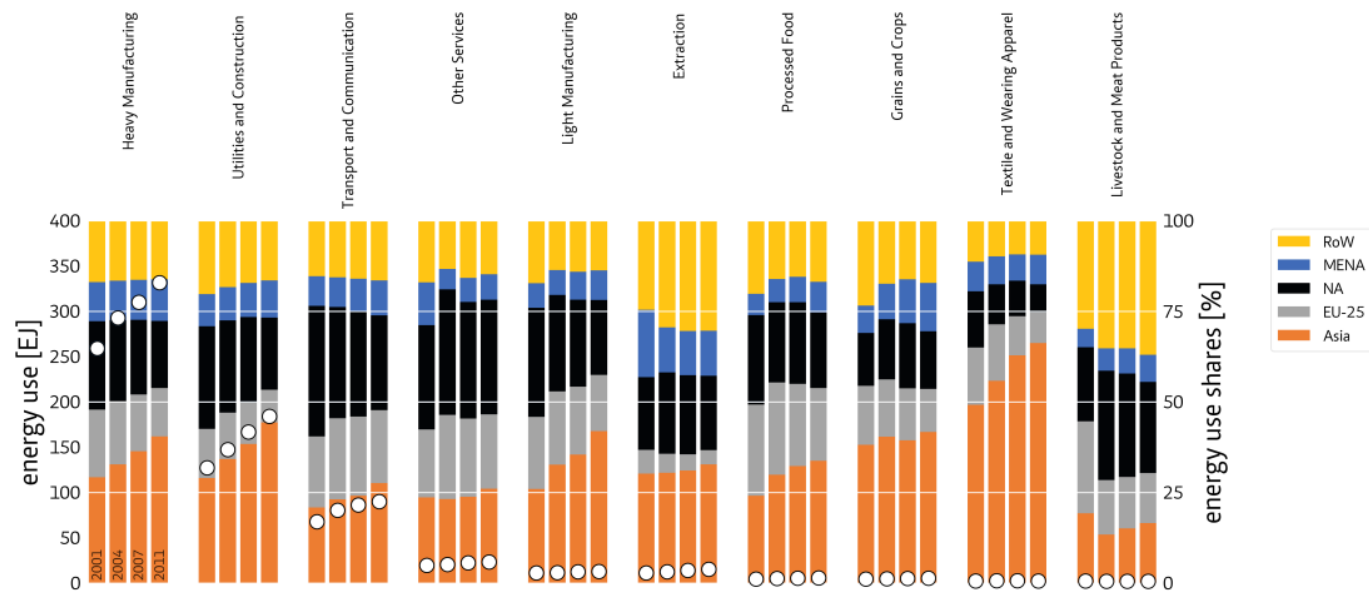

\begin{tabular}{|c|c|c|c|c|}
\hline Year & 2001 & 2004 & 2007 & 2011 \\
\hline Total Energy Use [EJ] & $\underline{511.4}$ & 581.3 & $\underline{628.5}$ & 674.3 \\
\hline Heavy Manufacturing & 259.3 & 292.8 & 310.1 & 331.9 \\
\hline Utilities and Construction & 127.4 & 147.6 & 167.1 & 184.1 \\
\hline Transport and Communication & 67.9 & 80.5 & 86.4 & 90.2 \\
\hline Other Services & 19.7 & 20.8 & 22.4 & 23.4 \\
\hline Light Manufacturing & 11.6 & 11.7 & 12.5 & 12.9 \\
\hline Extraction & 11.5 & 12.7 & 14.2 & 15.5 \\
\hline Processed Food & 4.6 & 5.4 & 5.5 & 5.9 \\
\hline Grains and Crops & 4.5 & 5.0 & 5.3 & 5.6 \\
\hline Textile and Wearing Apparel & 2.6 & 2.7 & 2.7 & 2.6 \\
\hline Livestock and Meat Products & 2.5 & 2.1 & 2.2 & 2.3 \\
\hline
\end{tabular}

Figure 2: Total energy use in EJ (circles, left axis) and regional shares (bars, right axis) per region and sector for 2001, 2004, 2007 and 2011, respectively (RoW = Rest of the World, MENA = Middle East and Northern Africa, NA = North America, EU-25 = European Union of 25 members, see table A4 in the Appendix for more detail). Table shows sectoral energy use in EJ for different years.

\subsection{Decomposition}

In order to understand the energy consumption patterns observed, we apply the decomposition technique described in Section 2. Results are summarized in Figure 3. 


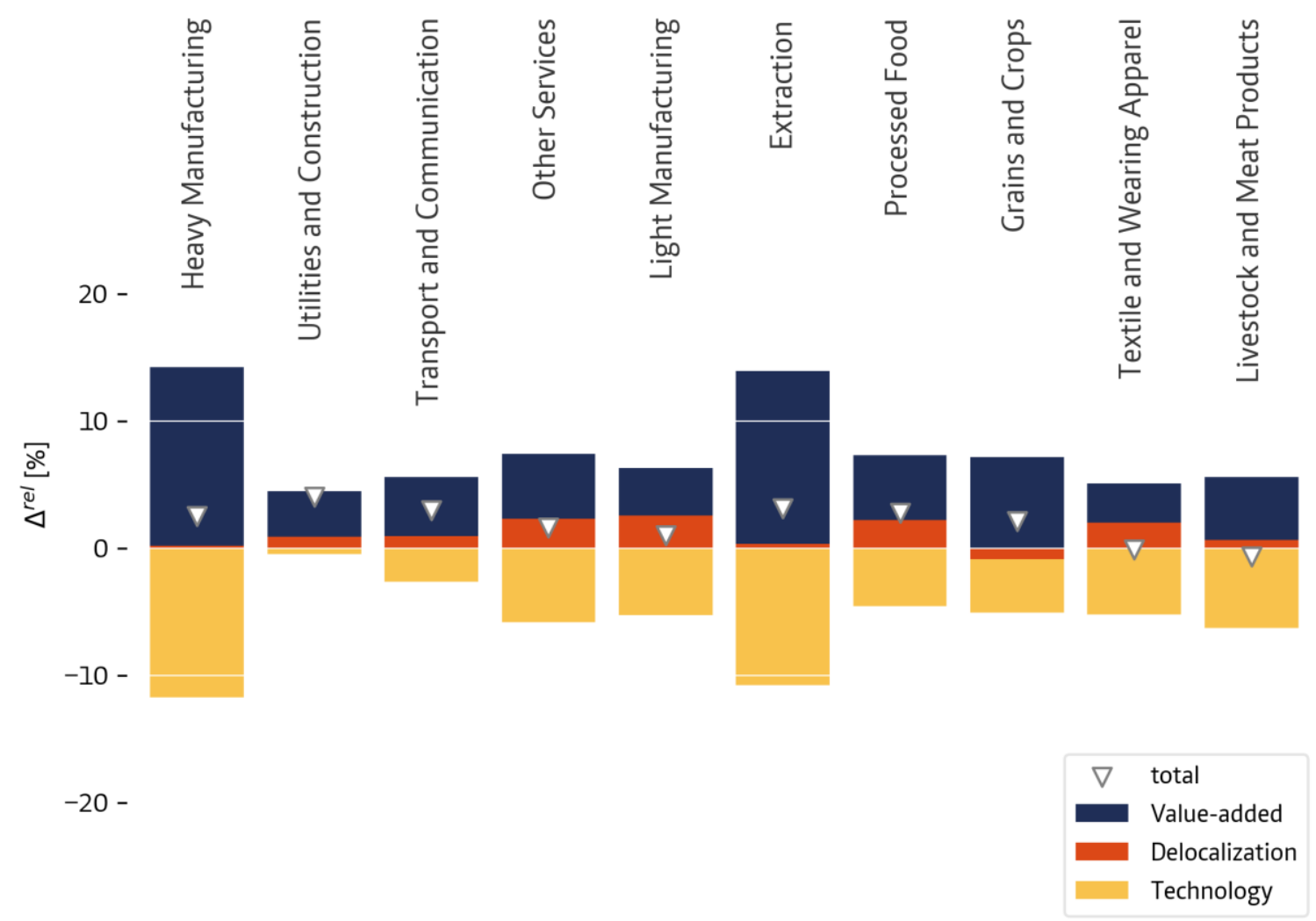

Figure 3: Average annual contributions to changes in energy usage of macro sectors by the technology, delocalization and sectoral value added factors for the period 2001-2011.

For all macro sectors, growth in the sectoral value added factor contributed to increases in energy usage. On average, its effect on energy use was 3-7\% per year. The largest average contributions (10-15\%) were observed in the "Heavy Manufacturing" and "Extraction" sectors. The increase in the latter could be a side effect of increases in the former, as extracted resources are relevant inputs for "Heavy Manufacturing". In contrast, technological improvements have constantly led to decreasing energy consumption, almost equating to the increases from value added contributions. For the entire period, delocalization has shown to have smaller impacts $(<5 \%)$. Only one sector, "Grains and Crops", saw decreases in energy consumption due to delocalization. In 
contrast, two of the three most important energy consuming macro sectors, "Utilities and Construction" and "Transport and Communication" witnessed a growth in delocalization-driven energy use. As both macro sectors largely reflect infrastructure, the observed delocalization could be driven by large (necessary) investments to build-up and improve infrastructure in China, India and other Asian economies (Schäfer, 2005; Steckel et al., 2013; Steinberger et al., 2010), which is already provided in OECD countries.

Investigating delocalization for macro sectors in more detail, i.e. considering all periods separately, reveals a different picture, see Figure 4.

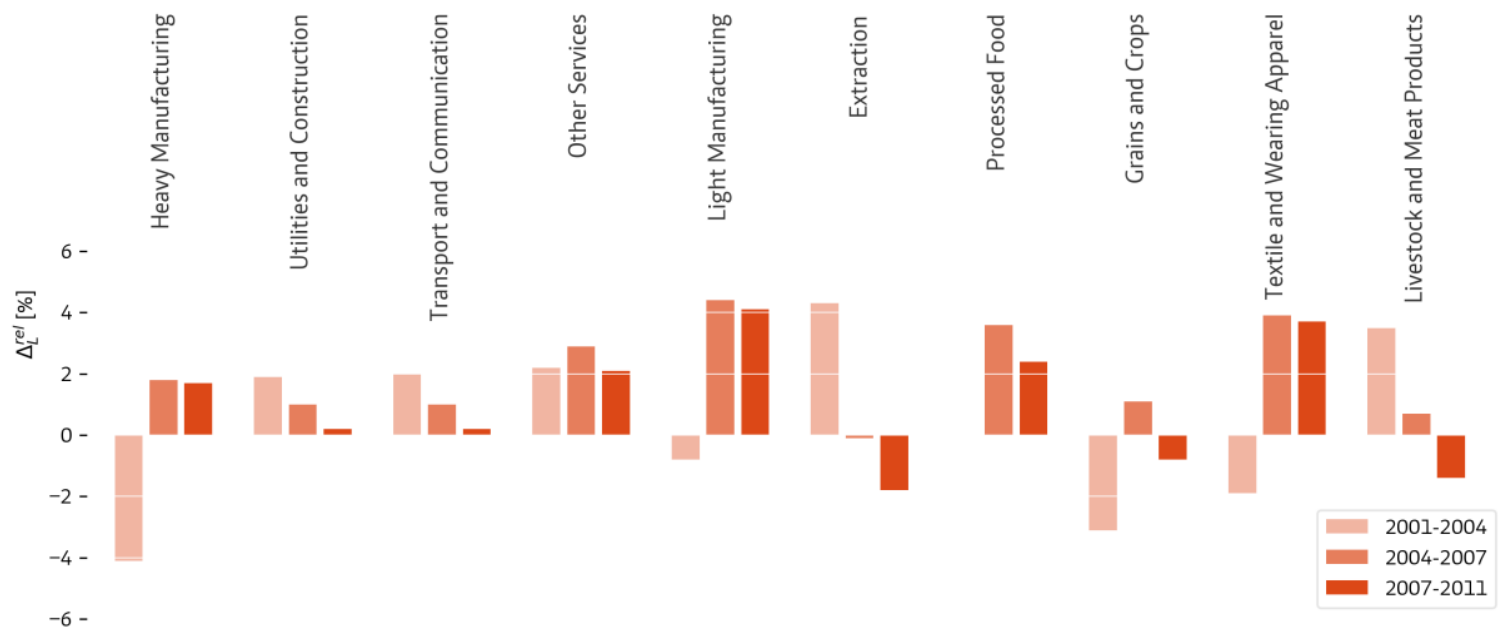

Figure 4: Delocalization effects at macro level. Annual percentage changes in energy intensities of macro sectors caused by delocalization. ${ }^{5}$

"Utilities and Construction", "Other services" and "Transport and Communication" are the only sectors that had a one-directional contribution and hence confirm the aggregated results when

5 Effects for macro sectors are derived by summing the effects of micro sectors. 
looking at separate periods. Nevertheless, the former two reveal a decreasing delocalization rate. For all other sectors, there are significant variations in contributions of delocalization, with five sectors experiencing a reverse in the trend. The positive effect of delocalization on energy intensities of "Livestock and Meat Products" and "Extraction" in 2001-2004 reversed in the subsequent periods. The opposite is true for "Heavy Manufacturing", "Light Manufacturing" and "Textiles and Wearing Apparel", which recently (after 2004) witnessed relevant relative production shift to less energy efficient production locations ${ }^{6}$. Such effects have been indicated by observed structural changes in economies (Voigt et al., 2014) and the decline in US manufacturing (Acemoglu et al., 2016). They might be inter alia related to an increasing competitiveness of Asian economies in manufacturing sectors (McMillan et al., 2014; Rodrik, 2015).

Assessing contributions of change in technology at a more detailed level by increasing the temporal resolution, see Figure 5, shows a rather constant cross-sectoral contribution of energy efficiency improvements to the decrease in energy use.

6 The energy-intensive trade-exposed sectors (EITE) include glass, steel, metals, pulp and paper, aluminum and chemicals (ACEEE, 2017). Hence, EITE sectors subsets part of “Heavy Manufacturing" and "Light Manufacturing”. 


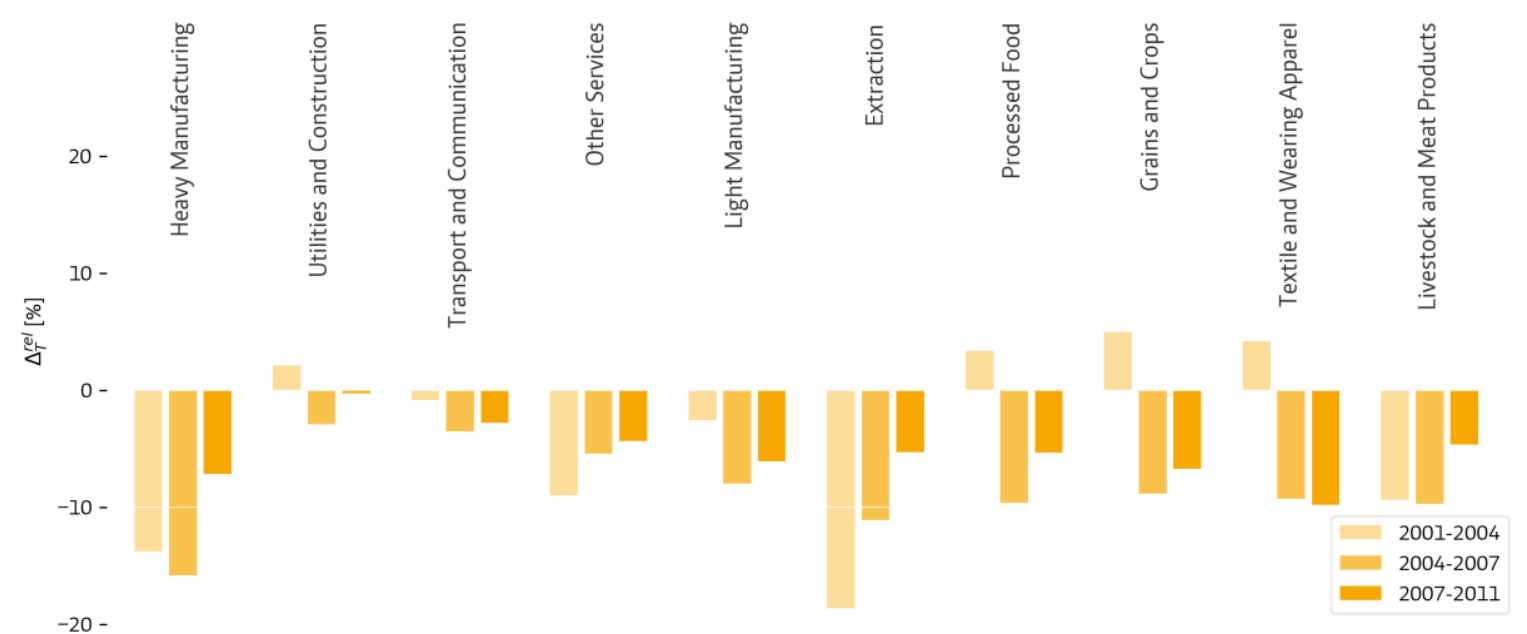

Figure 5: Annual percentage changes in sectoral energy intensities of macro sectors related to changes in the technology factor.

Even though some variance exists, only "Utilities and Construction", "Textiles and Wearing Apparel", "Grains and Crops" and "Processed Food" have a single period of positive contributions to energy consumption through changing technology. They are the only macro sectors that have seen a change in trend. Some sectors have experienced constantly decreasing improvement rates, i.e. "Extraction" and "Other services". A recent decline in the improvement rate of more than 8 percentage points in "Heavy Manufacturing" is particular interesting in this respect as it is the largest energy consuming macro sector ( $\sim 50 \%$ of world energy consumption). Note that in addition to this trend the delocalization factor for the same sector contributes to increases in energy intensities since 2004 (see also Figure 4).

As the macroeconomic sectors consist of multiple, non-homogeneous sectors, with contrasting shares of energy consumption, see Figure 2 and Table $A 3$, a more detailed investigation is indispensable to understand observed developments at the macro sectoral level. Investigating the most relevant macro sector "Heavy Manufacturing" in more detail, see Table 2, we find substantial internal heterogeneity across the effects. While the dominant sector "Petroleum and 
Coal Products" has shown very little changes due to delocalization ${ }^{7}$, all other sectors except for "Mineral Products nec"'s first period, i.e. "Chemical, Rubber and Plastics", "Ferrous Metals", "Metals nec", "Machinery and Equipment" and "Electronic Equipment" demonstrate continuous and relevant increases in energy consumption due to delocalization. The contributions of "Ferrous Metals" and "Machinery and Equipment" have exceeded 4\% for the entire period. For all cases, except for "Mineral Products nec" and "Electronic Equipment" in 2001-2004, delocalization-driven energy use increases are outweighed by technology effects. Observed reductions in energy intensity improvements also hold for all "Heavy Manufacturing" subsectors. Large reductions are identified for "Petroleum and Coal Products", "Ferrous Metals", "Metals nec" and "Machinery and Equipment nec". Please see the Discussion for potential reasons.

Also for other macro sectors, delocalization is relevant at the sub level. For the second and third most energy consuming macro sectors, i.e. "Utilities and Construction" and "Transportation and Communications", the subsectors "Electricity", "Construction", "Water" and "Communication" show continuously increasing energy consumption due to delocalization.

Taken together, subsectors of the three highest energy consuming macro sectors, showing continuously positive delocalization effects, accounted for approximately 280 Exajoules in 2011. That corresponds to more than $40 \%$ of global annual energy use and illustrates that delocalization is a relevant issue. In total, we observe that over the period 23 out of 57 GTAP sectors have constantly contributed to growing energy consumption due to delocalization. Seven sectors have constantly contributed to increases greater than 3\%: "Ferrous metals", "Machinery and Equipment", "Construction", "Communication", "Motor Vehicles and Parts", "Dwellings" and "Transport Equipment". In contrast, only two sectors have demonstrated a constant decrease in their energy consumption due to delocalization: "Oil seeds" and "Sugar", possibly because of delocalization towards more productive regions, i.e. Brazil in case of "Oil seeds" (Bustos et al.,

\footnotetext{
7 This sector is dependent on local endowments, thus finding little influence of delocalization makes perfect sense.
} 
2016). The more detailed decomposition of micro sectors (see Table 2) confirms that changes in sectoral value added have primarily contributed to increasing energy use.

The contrary is true for technology development. Both findings are in line with observations at aggregated sectoral level. Remarkably, the contribution of value added significantly declined in 2007-2011 compared to 2004-2007 for almost all sectors. This is possibly because of the global crisis in 2008 , see the Discussion for more detail.

\begin{tabular}{|c|c|c|c|c|c|c|c|c|c|}
\hline \multirow{2}{*}{$\begin{array}{l}\text { Factor } \\
\text { Year }\end{array}$} & \multicolumn{3}{|c|}{ Delocalization } & \multicolumn{3}{|c|}{ Technology } & \multicolumn{3}{|c|}{ Value added } \\
\hline & $\begin{array}{l}2001- \\
2004 \\
\end{array}$ & $\begin{array}{l}2004- \\
2007 \\
\end{array}$ & $\begin{array}{l}2007- \\
2011 \\
\end{array}$ & $\begin{array}{l}2001- \\
2004 \\
\end{array}$ & $\begin{array}{l}2004- \\
2007 \\
\end{array}$ & $\begin{array}{l}2007- \\
2011 \\
\end{array}$ & $\begin{array}{l}2001- \\
2004 \\
\end{array}$ & $\begin{array}{l}2004- \\
2007 \\
\end{array}$ & $\begin{array}{l}2007- \\
2011 \\
\end{array}$ \\
\hline $\begin{array}{l}\text { Heavy } \\
\text { Manufacturing }\end{array}$ & -4.1 & 1.8 & 1.7 & -13.8 & -15.8 & -7.1 & 22.0 & 15.9 & 7.2 \\
\hline P_C & -5.9 & 0.9 & 1.0 & -17.9 & -18.6 & -7.8 & 27.4 & 19.0 & 8.0 \\
\hline$C R P$ & 0.4 & 3.3 & 2.8 & -2.9 & -6.3 & -4.9 & 6.3 & 6.2 & 5.0 \\
\hline I_S & 4.9 & 5.3 & 4.0 & -9.9 & -9.1 & -4.5 & 12.7 & 8.8 & 5.5 \\
\hline NMM & -3.1 & 6.0 & 5.3 & 14.9 & -10.5 & -8.2 & 0.7 & 8.8 & 5.3 \\
\hline$N F M$ & 5.5 & 4.0 & 1.0 & -13.5 & -13.5 & -5.8 & 10.3 & 11.1 & 6.9 \\
\hline$O M E$ & 4.9 & 5.9 & 5.2 & -6.2 & -11.1 & -4.4 & 8.1 & 7.4 & 3.3 \\
\hline$E L E$ & 4.0 & 1.8 & 2.9 & 17.6 & -4.0 & -3.3 & -4.4 & 4.0 & 2.7 \\
\hline $\begin{array}{l}\text { Utilities and } \\
\text { Construction }\end{array}$ & 1.9 & 1.0 & 0.2 & 2.1 & -2.9 & -0.3 & 1.3 & 6.3 & 2.6 \\
\hline$E L Y$ & 1.9 & 0.8 & 0.2 & 3.1 & -2.4 & -0.3 & 0.5 & 6.0 & 2.8 \\
\hline$G D T$ & 0.4 & 2.3 & -2.4 & -16.9 & -11.1 & 4.3 & 14.8 & 13.1 & -1.3 \\
\hline CNS & 3.2 & 4.7 & 3.9 & 3.8 & -7.3 & -7.1 & 10.4 & 8.6 & 2.0 \\
\hline WTR & 5.0 & 5.9 & 1.9 & -8.7 & -7.7 & -2.8 & 5.0 & 7.7 & 3.7 \\
\hline $\begin{array}{l}\text { Transport and } \\
\text { Communication }\end{array}$ & 2.0 & 1.0 & 0.2 & $\begin{array}{l}-0.8 \\
\end{array}$ & -3.5 & -2.8 & 5.0 & 4.9 & 3.6 \\
\hline OTP & 1.5 & 1.3 & -0.1 & -0.9 & -3.5 & -2.5 & 6.1 & 4.7 & 3.7 \\
\hline ATP & 2.7 & 0.1 & 0.0 & -1.5 & -2.5 & -1.5 & 2.2 & 3.7 & 1.5 \\
\hline$T R D$ & -1.2 & 1.6 & 1.3 & 3.1 & -4.7 & -3.9 & 1.1 & 5.6 & 3.6 \\
\hline WTP & 8.6 & -0.1 & 0.6 & -4.6 & -3.9 & -4.7 & 9.8 & 8.1 & 6.8 \\
\hline$C M N$ & 3.0 & 5.1 & 4.4 & -7.0 & -6.1 & -5.8 & 10.1 & 6.7 & 3.8 \\
\hline Other Services & 2.2 & 2.9 & 2.1 & -9.0 & -5.4 & -4.3 & 8.3 & 5.2 & 3.2 \\
\hline OSG & 1.3 & 2.8 & 2.3 & -6.8 & -5.3 & -4.9 & 13.6 & 5.1 & 3.8 \\
\hline ROS & 1.7 & 1.4 & 1.7 & -11.5 & -4.3 & -4.0 & -3.4 & 4.7 & 3.1 \\
\hline$O B S$ & 4.0 & 3.9 & 2.0 & -8.2 & -6.1 & -3.4 & 9.3 & 5.6 & 2.0 \\
\hline OFI & 6.0 & 2.8 & 1.6 & -16.8 & -5.6 & -3.3 & 12.0 & 6.0 & 3.4 \\
\hline$I S R$ & 1.5 & 6.7 & 4.2 & -17.5 & -6.5 & -4.4 & 7.4 & 4.5 & 3.0 \\
\hline DWE & 11.2 & 5.3 & 3.7 & 0 & -8.3 & -1.1 & 26.1 & 3.8 & 3.2 \\
\hline $\begin{array}{l}\text { Light } \\
\text { Manufacturing }\end{array}$ & -0.8 & 4.4 & 4.1 & -2.5 & -8.0 & -6.0 & 3.8 & 5.7 & 2.7 \\
\hline$P P P$ & -2.1 & 3.6 & 3.1 & 0.8 & -6.9 & -7.4 & 2.4 & 4.6 & 2.6 \\
\hline$F M P$ & -1.8 & 6.5 & 6.5 & -7.9 & -8.8 & -4.6 & 7.1 & 6.6 & 2.1 \\
\hline$M V H$ & 4.2 & 3.4 & 3.9 & -10.6 & -4.1 & -4.7 & 7.3 & 6.9 & 2.5 \\
\hline LUM & 5.9 & 6.4 & 2.6 & -7.4 & -16.9 & -2.2 & 1.5 & 4.9 & 0.8 \\
\hline$O M F$ & -7.6 & 3.7 & 4.9 & 8.0 & -7.1 & -6.8 & 2.0 & 8.4 & 5.2 \\
\hline
\end{tabular}




\begin{tabular}{|c|c|c|c|c|c|c|c|c|c|}
\hline OTN & 3.3 & 3.9 & 5.3 & -8.8 & -4.2 & -5.2 & 6.0 & 7.1 & 3.8 \\
\hline$L E A$ & -4.3 & 4.1 & 3.1 & 8.0 & -10.9 & -11.1 & 3.7 & 6.6 & 4.7 \\
\hline Extraction & 4.3 & -0.1 & -1.8 & -18.6 & -11.1 & -5.3 & 17.9 & 15.0 & 9.4 \\
\hline OIL & 0.5 & -0.8 & 0.3 & -34.4 & -15.8 & -8.4 & 30.6 & 17.4 & 8.3 \\
\hline GAS & 6.0 & -3.2 & -10.0 & -12.4 & -9.1 & 7.2 & 12.1 & 13.2 & 4.7 \\
\hline$O M N$ & 0.0 & 1.6 & 0.9 & -6.5 & -5.8 & -7.9 & 18.1 & 16.5 & 10.7 \\
\hline$F S H$ & 0.6 & -2.7 & -2.3 & -2.1 & -7.1 & -6.5 & -4.3 & 10.0 & 10.8 \\
\hline$C O A$ & 27.4 & 3.9 & -0.2 & -16.5 & -13.4 & -9.9 & 11.4 & 13.5 & 15.1 \\
\hline FRS & 3.3 & 2.6 & -2.4 & -4.0 & -8.5 & -2.4 & 3.0 & 10.5 & 5.9 \\
\hline Processed Food & 0.0 & 3.6 & 2.4 & 3.4 & -9.6 & -5.3 & 2.8 & 7.1 & 4.7 \\
\hline OFD & 0.2 & 3.5 & 2.7 & -0.2 & -8.8 & -4.9 & 6.6 & 6.0 & 4.4 \\
\hline$B_{-} T$ & -4.3 & 5.2 & 2.8 & 19.7 & -8.8 & -7.2 & -1.9 & 5.5 & 4.5 \\
\hline$\overline{M I L}$ & 6.7 & 4.8 & 2.6 & 0.3 & -13.2 & -4.0 & 9.1 & 8.8 & 3.4 \\
\hline$S G R$ & -5.9 & -2.1 & -2.4 & -3.0 & -6.0 & -2.8 & -7.7 & 10.6 & 5.9 \\
\hline VOL & 6.5 & -0.6 & 1.8 & -0.2 & -13.5 & -6.8 & -6.9 & 15.5 & 10.2 \\
\hline Grains and Crops & -3.1 & 1.1 & -0.8 & 5.0 & -8.8 & -6.7 & 1.9 & 9.2 & 9.0 \\
\hline$V_{-} F$ & 0 & 0.6 & -1.4 & 1.2 & -7.6 & -6.2 & 2.3 & 9.3 & 7.5 \\
\hline$O C R$ & -2.5 & 0.0 & -1.7 & 2.3 & -8.1 & -4.2 & 2.2 & 3.8 & 4.9 \\
\hline WHT & -13.4 & 2.5 & 1.9 & 15.1 & -10.6 & -6.5 & -1.0 & 11.4 & 9.3 \\
\hline GRO & -0.8 & 3.2 & -1.4 & 5.9 & -11.6 & -7.4 & 5.0 & 16.5 & 10.2 \\
\hline$P C R$ & -12.9 & 4.5 & 0.4 & 0.5 & -9.7 & -5.6 & -7.3 & 12.8 & 11.6 \\
\hline OSD & -1.5 & -0.2 & -1.7 & 7.6 & -9.5 & -7.7 & 16.5 & 9.3 & 11.3 \\
\hline PFB & -0.3 & 0.9 & 1.8 & 11.0 & -8.5 & -12.5 & -3.4 & 6.9 & 12.7 \\
\hline$P D R$ & 5.9 & 0.2 & -1.9 & 5.6 & -7.2 & -8.2 & 1.2 & 6.5 & 14.0 \\
\hline C_B & 0.2 & 1.6 & 0.2 & 3.9 & -9.8 & -7.5 & 1.0 & 9.9 & 14.7 \\
\hline $\begin{array}{l}\text { Textile and } \\
\text { Wearing Apparel }\end{array}$ & -1.9 & 3.9 & 3.7 & 4.2 & -9.3 & -9.8 & $\begin{array}{ll}-1.1 \\
\end{array}$ & 5.9 & 4.5 \\
\hline TEX & -2.7 & 3.9 & 3.8 & 1.7 & -8.9 & -9.3 & -1.1 & 5.9 & 4.8 \\
\hline WAP & 1.1 & 4.0 & 3.5 & 13.7 & -10.1 & -11.2 & -1.0 & 6.0 & 3.8 \\
\hline $\begin{array}{l}\text { Livestock and Meat } \\
\text { Products }\end{array}$ & 3.5 & 0.1 & -1.4 & -9.4 & -9.7 & -4.6 & 1.0 & 10.2 & 7.2 \\
\hline OAP & 2.8 & -1.9 & -1.1 & -11.9 & -8.2 & -5.7 & -0.1 & 11.0 & 8.1 \\
\hline$R M K$ & 8.7 & -1.3 & -1.9 & -17.2 & -8.6 & -3.9 & 3.0 & 9.4 & 7.0 \\
\hline OMT & -1.7 & -0.6 & 0.1 & -6.1 & -12.0 & -2.9 & -0.1 & 10.9 & 3.5 \\
\hline$C T L$ & 3.0 & -0.3 & -4.0 & -8.4 & -9.0 & -5.6 & 2.7 & 8.2 & 10.5 \\
\hline CMT & 4.3 & 5.3 & -0.6 & -3.0 & -11.3 & -3.7 & 1.8 & 9.8 & 5.3 \\
\hline WOL & 7.8 & 1.3 & 0.5 & 19.5 & -11.9 & -7.9 & -10.5 & 16.1 & 13.8 \\
\hline
\end{tabular}

Table 2: Annual relative changes in energy use in percent, decomposed to the relative delocalization, energy efficiency and sectoral value added factors. Sorting of macro sectors and internal sorting of subsectors follows the share of energy consumption (see Table $\mathbf{A} 3$ in the Appendix).

\section{Discussion and Conclusion}

In this paper, we investigate the role of delocalization on annual changes in sectoral energy use for the period 2001-2011. Within this decade global energy use increased by one third, and sectoral energy use patterns have shifted significantly between regions. Our results, using a LMDI decomposition along sectoral lines, show that increases in (sectoral) value added have 
continuously been the dominating factor and boosted overall energy use. This effect is partly counterbalanced by technological improvements, which have, however, decelerated over time, at least for most energy intensive sectors. Although delocalization does not show a clear crosssectoral trend, in most sectors it has increased energy consumption within the range of 1-6\% per annum. This holds especially for sectors with high overall energy consumption.

Manufacturing sectors show a strong increase in production shares in more energy-intensive regions since 2004. More specifically, "Ferrous metals", "Machinery and Equipment", "Construction", "Communication", "Motor Vehicle and Parts", "Dwellings" and "Transport Equipment" have experienced constant annual delocalization-driven increases of energy use by more than 3\% per annum for the entire period (2001-2011). It is important to note that those manufacturing sectors are among the most flexible in terms of production location in the global economy (McMillan et al., 2014; Rodrik, 2015). Production can hence adjust relatively easily to changes in political or economic framework conditions. This could imply that an increasing segregation of climate policy across the world might well accelerate the delocalization of energyintensive sectors from regulated towards non-regulated regions, leading to overall increasing energy demand and hence emissions. At least, our results give no indication that a stronger delocalization trend, which could be caused by environmental regulation, increases energy intensity improvement rates, as theoretically laid out by Gerlagh and Kuik (2014) and Grubb et al. (2002).

It is important to note that from a global perspective it seems as technological improvement rates in some manufacturing sectors also slow down in subsequence of delocalization, see Table 2 . This coincides with technological research capacities and abilities to adopt efficient technologies being (currently) mainly located in industrialized countries (Dechezleprêtre et al., 2013, 2011). Delocalization might hence induce second order effects that impede achieving ambitious climate change mitigation as future energy intensity progress rates are negatively impacted. Our small sample does not allow to investigate this hypothesis statistically. In addition, other explanations 
need to be considered. Thus the global economic crises in $2008 / 2009^{8}$, which majorly hit OECD economies (China for instance experienced only small impacts on GDP growth rates (The World Bank, 2017)) and led to declines in oil prices (Nasdaq, 2017) could have had relevant influence on the observed decline in energy intensity improvement rates (Csereklyei et al., 2016; Dechezleprêtre et al., 2011).

The applied approach allows to identify the pure sectoral relative delocalization effects within single sectors ${ }^{9}$, which has not been done before. However, our analysis does not allow to give an ex-post explanation for the effects observed. ${ }^{10}$ Nevertheless, multiple theoretical explanations and channels have been identified (Dechezleprêtre and Sato, 2017). An approximate understanding of potential policy impacts and their dynamics can currently only be gained by the application and evaluation of CGE models (Carbone and Rivers, 2017).

Considering the ambitious climate mitigation targets laid down in the Paris Agreement it is important to understand how the impacts associated to observed delocalization can be alleviated. Targeting emissions in specific economic sectors across all countries (or at least a relevant set of countries, e.g. within the G20) might be an effective and feasible second best option for climate policy as long as no global approach exists. Negotiations on specific targets or regulations could be faster and implementation easier compared to economy wide approaches (Ahman et al., 2016; den Elzen et al., 2008; Kuik et al., 2008; Schmidt et al., 2008). Such mitigation strategies might be

8 Note that according to Figure 1, the Middle East, Southern and East Asia saw significant increases in energy consumption for 2007-2011, while North America and the EU25 saw declines. The increases overcompensated the declines. Nevertheless, in subsequence of the global economic crisis, the growth rate of energy consumption declined (The annual growth rate for $2007-2011$ is $5.5 \%$ compared to $8.2 \%$ (2004-2007) and 13.6\% (2001-2004)).

9 This also implies that we can depict the real sectoral energy intensity progress rate as delocalization effects can be segregated.

10 Inter alia no policy counterfactual exists and hence effects cannot be disentangled to their origin. 
particularly feasible for manufacturing sectors, which are both prone to delocalization, responsible for a large share of energy consumption and show large efficiency variations across countries (Kim and Kim, 2012; Saygin et al., 2011). Given that manufacturing sectors also imply significant energy consumption in their supply chains, targeting selected energy intensive sectors might imply significant reductions in both, energy consumption and emissions in upstream sectors (Ward et al., 2017).

How to organize and incentivize intra-sectoral technology transfer is open to debate. Targeted development assistance and foreign direct investments could foster technological progress in developing countries (Javorcik, 2004; Peterson, 2008). One additional possibility would be to make entire sectors (e.g., in the form of industry associations) eligible for climate finance, for instance to enforce sector wide efficiency standards (Saygin et al., 2011) or targeted technological access (United Nations, 1992). Nevertheless, intellectual property rights in developing countries that have been identified as a major obstacle to technological progress and diffusion of efficient technologies will have to improve (Dechezleprêtre et al., 2013).

Carbon tariffs are frequently proposed to tackle delocalization resulting from environmental regulation, more specifically emission leakage (Böhringer et al., 2012). Our results do not necessarily support this claim. They do not allow to disentangle whether observed delocalization is caused by existing differences in environmental regulation (Jakob et al., 2014), differences in productivity as described by Rodrik (2015), ongoing fragmentation and specialization in global supply networks (Timmer et al., 2014) or differing regional growth dynamics leading to relative shifts in the production network (Voigt et al., 2014). Further, it is unclear whether delocalizing sectors are primarily producing for export or for domestic demand (Jakob et al. 2013). It is hence questionable whether carbon tariffs would trigger technological improvements in countries using inefficient technologies and thus abate impacts by delocalization. Future research could focus on trade patterns of delocalizing sectors along the lines of the sectoral decomposition we propose. 


\section{Acknowledgements}

The authors want to thank Sabine Fuss and Michael Jakob for their valuable comments on this work. In addition, we would like to thank two anonymous referees.

\section{Funding}

This work was supported by the German Research Association (Deutsche Forschungsgemeinschaft), Collaborative Research Center 1026. Hauke Ward gratefully acknowledges funding by the Bundesministerium für Bildung und Forschung (BMBF) grant "Klimapolitische Maßnahmen und Transformationspfade zur Begrenzung der globalen Erwärmung auf $1.5^{\circ} \mathrm{C}$ (PEP1p5)", with grant number 01LS1610B.

\section{Statement on figure colors}

No color should be used for any figures in print. 


\section{References}

ACEEE, 2017. Energy-Intensive, Trade-Exposed Industries. URL: http://aceee.org/topics/energyintensive-trade-exposed-industries, accessed 2017-07-31

Acemoglu, D., Autor, D., Dorn, D., Hanson, G.H., 2016. Import Competition and the Great US Employment Sag of the 2000s. J. Labor Econ. 34, 141-198.

Aguiar, A., Narayanan, B., McDougall, R., 2016. An Overview of the GTAP 9 Data Base. J. Glob. Econ. Anal. 1, 181-208.

Ahman, M., Nilsson, L.J., Johansson, B., 2016. Global climate policy and deep decarbonization of energy-intensive industries. Clim. Change Econ. in press, 1-16.

Alexeeva-Talebi, V., Boehringer, C., Löschel, A., Voigt, S., 2012. The value-added of sectoral disaggregation: Implications on competitive consequences of climate change policies. Energy Econ. 34, 127-142.

Andrew, R., Peters, G.P., 2013. A Multi-Region Input-Output Table Based on the Global Trade Analysis Project Database (GTAP-MRIO). Econ. Syst. Res. 25, 99-121.

Ang, B.W., 2015. LMDI decomposition approach: A guide for implementation. Energy Policy 86, 233-238.

Ang, B.W., Wang, H., 2015. Index decomposition analysis with multidimensional and multilevel energy data. Energy Econ. 51, 67-76.

Baldwin, R.E., Martin, P., 1999. Two Waves of Globalization: Superficial Similarities, fundamental Differences. NBER Work. Pap. 6904.

Böhringer, C., Balistreri, E.J., Rutherford, T.F., 2012. The role of border carbon adjustment in unilateral climate policy: Overview of an Energy Modeling Forum study (EMF 29). Energy Econ. 34, 97-110.

Branger, F., Quirion, P., 2015. Reaping the carbon rent: Abatement and overallocation profits in the European cement industry, insights from an LMDI decomposition analysis. Energy Econ. 47, 189-205.

Branger, F., Quirion, P., 2014. Would border carbon adjustments prevent carbon leakage and heavy industry competitiveness losses? Insights from a meta-analysis of recent economic studies. Ecol. Econ. 99, 29-39.

Bustos, P., Caprettini, B., Ponticelli, J., 2016. Agricultural productivity and structural transformation: Evidence from Brazil. Am. Econ. Rev. 106, 1320-1365. 
Carbone, J.C., Rivers, N., 2017. The Impacts of Unilateral Climate Policy on Competitiveness: Evidence From Computable General Equilibrium Models. Rev. Environ. Econ. Policy 11, $24-42$.

Cole, M.A., Elliott, R.J.R., Fredriksson, P.G., 2006. Endogenous pollution havens: Does FDI in uence environmental regulations? Scand. J. Econ. 108, 157-178.

Cramton, P., MacKay, D.J.C., Ockenfels, A., Stoft, S. (Eds.), 2017. Global Carbon Pricing. MIT Press, Cambridge, MA, USA.

Csereklyei, Z., Rubio Varas, M. d. M., Stern, D.I., 2016. Energy and Economic Growth: The Stylized Facts. Energy J. 37, 223-255.

Dechezleprêtre, A., Glachant, M., Hascic, I., Johnstone, N., Meniere, Y., 2011. Invention and Transfer of Climate Change-Mitigation Technologies: A Global Analysis. Rev. Environ. Econ. Policy 5, 109-130.

Dechezleprêtre, A., Glachant, M., Ménière, 2013. What Drives the International Transfer of Climate Change Mitigation Technologies? Empirical Evidence from Patent Data. Environ. Resour. Econ. 54, 161-178.

Dechezleprêtre, A., Sato, M., 2017. The impacts of environmental regulations on competitiveness. Rev. Environ. Econ. Policy 11, 183-206.

den Elzen, M., Höhne, N., Moltmann, S., 2008. The Triptych approach revisited: A staged sectoral approach for climate mitigation. Energy Policy 36, 1107-1124. doi:10.1016/j.enpol.2007.11.026

Dietzenbacher, E., Mukhopadhyay, K., 2007. An Empirical Examination of the Pollution Haven Hypothesis for India: Towards a Green Leontief Paradox? Environ. Resour. Econ. 36, 427449.

Dimaranan, B.V., 2006. Global Trade, Assistance, and Production: The GTAP 6 Data Base.

Edenhofer, O., Jakob, M., Creutzig, F., Flachsland, C., Fuss, S., Kowarsch, M., Lessmann, K., Mattauch, L., Siegmeier, J., Steckel, J.C., 2015. Closing the emission price gap. Glob. Environ. Change 31, 132-143. doi:10.1016/j.gloenvcha.2015.01.003

Eskeland, G.S., Harrison, A.E., 2003. Moving to greener pastures? Multinationals and the pollution haven hypothesis. J. Dev. Econ. 70, 1-23.

Gerlagh, R., Kuik, O., 2014. Spill or leak? Carbon leakage with international technology spillovers: A CGE analysis. Energy Econ. 45, 381-388.

Grubb, M.J., Hope, C., Fouquet, R., 2002. Climatic Implications of the Kyoto Protocol: The Contribution of International Spillover. Clim. Change 54, 11-28. 
Jaffe, A.B., Peterson, S.R., Portney, P.R., Stavins, R.N., 1995. Environmental Regulation and the Competitiveness of U.S. Manufacturing: What Does the Evidence Tell Us? J. Econ. Lit. 33, $132-163$.

Jakob, M., Steckel, J.C., Edenhofer, O., 2014. Consumption- Versus Production-Based Emission Policies. Annu. Rev. Resour. Econ. 6, 297-318. doi:10.1146/annurev-resource-100913012342

Javorcik, B., 2004. Does Foreign Direct Investment Increase the Productivity of Domestic Firms? In Search of Spillovers Through Backward Linkages. Am. Econ. Rev. 94.

Kim, K., Kim, Y., 2012. International comparison of industrial 2 emission trends and the energy efficiency paradox utilizing production-based decomposition. Energy Econ. 34, 17241741.

Koopman, R., Wang, Z., Wei, S.-J., 2014. Tracing Value-Added and Double Counting in Gross Exports. Am. Econ. Rev. 104, 459-494. doi:10.1257/aer.104.2.459

Kuik, O., Aerts, J., Berkhout, F., Biermann, F., Bruggink, J., Joyeeta, G., Tol, R.S.J., 2008. Post2012 climate policy dilemmas: a review of proposals. Clim. Policy 8, 317-336.

Lee, H.-L., 2008. The Combustion-based 2 Emissions Data for GTAP Version 7 Data Base (No. 1143).

URL: https://www.gtap.agecon.purdue.edu/resources/res_display.asp?RecordID=1143, accessed 2014-11-05

Lenzen, M., Moran, D., Kanemoto, K., Geschke, A., 2013. Building Eora: A multi-region inputoutput database at high country and sector resolution. Econ. Syst. Res. 25, 20-49. doi:10.1080/09535314.2013.769938

Löschel, A., Pothen, F., Schymura, M., 2015. Peeling the onion: Analyzing aggregate, national and sectoral energy intensity in the European Union. Energy Econ. 52, 63-75.

MacKay, D.J.C., Cramton, P., Ockenfels, A., Stoft, S., 2015. Price carbon - I will if you will. Nature 526, 315-316. doi:10.1038/526315a

McMillan, M., Rodrik, D., Verduzco-Gallo, Í., 2014. Globalization, Structural Change, and Productivity Growth with an Update on Africa. World Dev. 63, 11-32. doi:10.1016/j.worlddev.2013.10.012

Narayanan, B.G., Aguiar, A., McDougall, Robert, 2015. Global Trade, Assistance, and Production: The GTAP 9 Data Base.

Nasdaq, 2017. End of day Commodity Futures Price Quotes for Crude Oil WTI - 10 years. URL: http://www.nasdaq.com/markets/crude-oil.aspx?timeframe=10y, accessed 2017-07-31 
Peters, G.P., Andrew, R., Lennox, J., 2011. Constructing an Environmentally-Extended MultiRegional Input-Output Table Using the GTAP Database. Econ. Syst. Res. 23, 131-152. doi:10.1080/09535314.2011.563234

Peterson, S., 2008. Greenhouse gas mitigation in developing countries through technology transfer?: a survey of empirical evidence. Mitig. Adapt. Strateg. Glob. Change 13, 283305 .

Rodrik, D., 2015. Premature deindustrialization. J. Econ. Growth 21, 1-33. doi:10.1007/s10887015-9122-3

Saygin, D., Worrell, E., Patel, M.K., Gielen, D.J., 2011. Benchmarking the energy use of energyintensive industries in industrialized and in developing countries. Energy 36, 6661-6673.

Schäfer, A., 2005. Structural change in energy use. Energy Policy 33, 429-437. doi:10.1016/j.enpol.2003.09.002

Schmidt, J., Helme, N., Lee, J., Houdashelt, M., 2008. Sector-based approach to the post-2012 climate change policy architecture. Clim. Policy 8, 494-515. doi:10.3763/cpol.2007.0321

Steckel, J.C., Brecha, R.J., Jakob, M., Strefler, J., Luderer, G., 2013. Development without energy? Assessing future scenarios of energy consumption in developing countries. Ecol. Econ. 90, 53-67. doi:doi:10.1016/j.ecolecon.2013.02.006

Steinberger, J.K., Krausmann, F., Eisenmenger, N., 2010. Global patterns of materials use: A socioeconomic and geophysical analysis. Ecol. Econ. 69, 1148-1158.

The World Bank, 2017. The World Bank - GDP annual growth rates - China. URL: (http://data.worldbank.org/indicator/NY.GDP.MKTP.KD.ZG?locations=CN, accessed 2017-07-31

Timmer, M., Dietzenbacher, E., Los, B., Stehrer, R., Vries, G.J., 2015. An Illustrated User Guide to the World Input-Output Database: the Case of Global Automotive Production. Rev. Int. Econ. 23, 575-605.

Timmer, M., Erumban, A., Los, B., Stehrer, R., de Vries, G., 2014. Slicing Up Global Value Chains. J. Econ. Perspect. 28, 99-118.

Tukker, A., Dietzenbacher, E., 2013. Global Multiregional Input-Output Frameworks: An Introduction and Outlook. Econ. Syst. Res. 25, 1-19. doi:10.1080/09535314.2012.761179

UNFCCC, 2015. Paris Agreement. URL: http://unfccc.int/files/essential_background/convention/application/pdf/english_paris_agre ement.pdf, accessed 2016-12-01

United Nations, 1992. United Nations Framework Convention on Climate Change. URL: https://unfccc.int/resource/docs/convkp/conveng.pdf, accessed 2016-11-14 
Voigt, S., De Cian, E., Schymura, M., Verdolini, E., 2014. Energy intensity developments in 40 major economies: Structural change or technology improvement? Energy Econ. 41, 47-62.

Ward, H., Radebach, A., Vierhaus, I., Fügenschuh, A., Steckel, J.C., 2017. Reducing global CO2 emissions with the technologies we have. Resour. Energy Econ. 49, 201-217.

Weitzman, M.L., 2014. Can Negotiating a Uniform Carbon Price Help to Internalize the Global Warming Externality? J. Assoc. Environ. Resour. Econ. 1, 29-49. doi:10.1086/676039

Worldbank, 2017. Inflation, GDP deflator (annual \%) [WWW Document]. URL https://data.worldbank.org/indicator/NY.GDP.DEFL.KD.ZG (accessed 17-09-26). 


\section{Appendix}

In GTAP, raw energy data are categorized according to three criteria. The first is the energy source or service: GTAP accounts for coal, gas, oil, electricity, petroleum and coal products and gas distribution. In the second, the origin is considered (domestic or imported). The third characteristic accounts for the type of final consumption where the energy is used (households, government use, company use). For the analysis carried out in this paper, only companies are used as they use energy in industrial production. Before energy data can be used in the decomposition analysis, the data has to be adapted to the input-output framework.

Single flows in GTAP raw energy use data consider the year $t$, sector $s$, region $r$, energy source $e$ and origin $o$ (domestic/import), so that each one can be written as $E_{s, r, t, e, o}$. First, values for imported and domestic energy for each energy source are totaled for each region and sector.

As energy flows are given in tons of oil equivalent (toe), they have to be transformed into Joules (J), the unit used by the International System and used in preference to indicate energy intensity $(\mathrm{J} / \$)$. Since the calorific value depends on the fuel considered, the transformation is carried out by applying energy-source dependent conversion coefficients $C C_{e}$ as displayed in Table A1.

\begin{tabular}{|l|l|}
\hline Energy commodity & conversion coefficient (MJ/toe) \\
\hline Coal & 41868 \\
\hline Crude oil & 41868 \\
\hline Natural gas & 41868 \\
\hline Electricity & 41868 \\
\hline Petroleum products & 44500 \\
\hline Gas products (mainly LPG) & 47310 \\
\hline
\end{tabular}

Table A1: Conversion coefficients for different energy commodities (Lee, 2008).

In the next step, the energy use for different energy sources is aggregated, since this differentiation is not relevant for our analysis. As a result, three $140 \times 57$ matrices (for 2011, 2007and 2004) and one $87 \times 57$ matrix (2001) emerge: 


$$
E_{s, r, t}=\sum_{e}\left(\sum_{o} E_{s, r, t, e, o} \cdot C C_{e}\right)
$$

As regions considered in GTAP versions 6 and 9 vary, it is necessary to harmonize the regional dimension. Regions that are available in GTAP 9 which are not separately covered in GTAP 6 are treated in a special way. Such regions are aggregated to the corresponding "X" ("rest of") region they geographically belong to, please see the corresponding GTAP manuals (Dimaranan, 2006; Narayanan et al., 2015). The Rest of the World (XTW) region was disregarded as it included different regions in the two versions. For this reason, we consider 86 regions instead of 87 that are available in GTAP 6 when analyzing development from 2001 to 2004.

The data contains regional sectors that have negative value added. Using those negative values would lead to negative energy intensities. For computational consistency we set all entries to zero (in both years for a decomposition analysis) if they exhibited negative value ex ante.

\begin{tabular}{|c|c|c|c|}
\hline \multicolumn{2}{|r|}{ sector } & \multicolumn{2}{|r|}{ macro sector } \\
\hline abbreviation & name & abbreviation & name \\
\hline PDR & Paddy rice & GrainsCrops & Grains and Crops \\
\hline GRO & Cereal grains nec & GrainsCrops & Grains and Crops \\
\hline V_F & Vegetables, fruit, nuts & GrainsCrops & Grains and Crops \\
\hline C_B & Sugar cane, sugar beet & GrainsCrops & Grains and Crops \\
\hline PFB & Plant-based fibers & GrainsCrops & Grains and Crops \\
\hline OCR & Crops nec & GrainsCrops & Grains and Crops \\
\hline CTL & Bovine cattle, sheep and goats, horses & MeatLstk & Livestock and Meat Products \\
\hline FRS & Forestry & Extraction & Mining and Extraction \\
\hline FSH & Fishing & Extraction & Mining and Extraction \\
\hline COA & Coal & Extraction & Mining and Extraction \\
\hline
\end{tabular}




\begin{tabular}{|c|c|c|c|}
\hline OIL & Oil & Extraction & Mining and Extraction \\
\hline GAS & Gas & Extraction & Mining and Extraction \\
\hline $\mathrm{OMN}$ & Minerals nec & Extraction & Mining and Extraction \\
\hline CMT & Bovine meat products & MeatLstk & Livestock and Meat Products \\
\hline OMT & Meat products nec & MeatLstk & Livestock and Meat Products \\
\hline VOL & Vegetable oils and fats & ProcFood & Processed Food \\
\hline MIL & Dairy products & ProcFood & Processed Food \\
\hline PCR & Processed rice & GrainsCrops & Grains and Crops \\
\hline SGR & Sugar & ProcFood & Processed Food \\
\hline OFD & Food products nec & ProcFood & Processed Food \\
\hline B_t & Beverages and tobacco products & ProcFood & Processed Food \\
\hline TEX & Textiles & TextWapp & Textile and Wearing Apparel \\
\hline WAP & Wearing apparel & TextWapp & Textile and Wearing Apparel \\
\hline LEA & Leather products & LightMnfc & Light Manufacturing \\
\hline LUM & Wood products & LightMnfc & Light Manufacturing \\
\hline PPP & Paper products, publishing & LightMnfc & Light Manufacturing \\
\hline P_C & Petroleum, coal products & HeavyMnfc & Heavy Manufacturing \\
\hline CRP & Chemical, rubber, plastic products & HeavyMnfc & Heavy Manufacturing \\
\hline NMM & Mineral products nec & HeavyMnfc & Heavy Manufacturing \\
\hline 1 & Ferrous metals & HeavyMnfc & Heavy Manufacturing \\
\hline NFM & Metals nec & HeavyMnfc & Heavy Manufacturing \\
\hline FMP & Metal products & LightMnfc & Light Manufacturing \\
\hline $\mathrm{MVH}$ & Motor vehicles and parts & LightMnfc & Light Manufacturing \\
\hline OTN & Transport equipment nec & LightMnfc & Light Manufacturing \\
\hline ELE & Electronic equipment & HeavyMnfc & Heavy Manufacturing \\
\hline $\mathrm{OME}$ & Machinery and equipment nec & HeavyMnfc & Heavy Manufacturing \\
\hline OMF & Manufactures nec & LightMnfc & Light Manufacturing \\
\hline ELY & Electricity & Util_Cons & Utilities and Construction \\
\hline GDT & Gasmanufacture, distribution & Util_Cons & Utilities and Construction \\
\hline WTR & Water & Util_Cons & Utilities and Construction \\
\hline CNS & Construction & Util_Cons & Utilities and Construction \\
\hline TRD & Trade & TransComm & Transport and Communication \\
\hline OTP & Transport nec & TransComm & Transport and Communication \\
\hline WTP & Water transport & TransComm & Transport and Communication \\
\hline ATP & Air transport & TransComm & Transport and Communication \\
\hline $\mathrm{CMN}$ & Communication & TransComm & Transport and Communication \\
\hline OFI & Financial services nec & OthServices & Other Services \\
\hline ISR & Insurance & OthServices & Other Services \\
\hline OBS & Business services nec & OthServices & Other Services \\
\hline ROS & Recreational and other services & OthServices & Other Services \\
\hline OSG & Public Adm., Defense, Education, Health & OthServices & Other Services \\
\hline DWE & Dwellings & OthServices & Other Services \\
\hline
\end{tabular}


Table A2: Sectors and macro sectors as from GTAP Data Base.

\begin{tabular}{|c|c|c|c|c|}
\hline Year & 2001 & 2004 & 2007 & 2011 \\
\hline Total & $\underline{511.4}$ & 581.3 & 628.5 & 674.3 \\
\hline Heavy Manufacturing & 259.3 & 292.8 & 310.1 & 331.9 \\
\hline P_C & 192.5 & 213.4 & 222.8 & 233.4 \\
\hline$C R P$ & 36.1 & 40.3 & 44.2 & 49.3 \\
\hline I_S & 11.4 & 14.0 & 16.2 & 19.3 \\
\hline NMM & 10.2 & 14.0 & 15.9 & 17.4 \\
\hline$N F M$ & 5.1 & 5.4 & 5.7 & 6.2 \\
\hline OME & 3.0 & 3.6 & 3.8 & 4.5 \\
\hline$E L E$ & 1.0 & 1.6 & 1.7 & 1.8 \\
\hline Utilities and Construction & 127.4 & 147.6 & 167.1 & 184.1 \\
\hline$E L Y$ & 118.6 & 138.1 & 156.2 & 173.0 \\
\hline$G D T$ & 5.5 & 5.3 & 6.0 & 6.1 \\
\hline CNS & 1.7 & 2.6 & 3.1 & 2.9 \\
\hline WTR & 1.5 & 1.5 & 1.8 & 2.1 \\
\hline Transport and Communication & 67.9 & 80.5 & 86.4 & 90.2 \\
\hline OTP & 38.4 & 46.3 & 49.8 & 52.0 \\
\hline ATP & 13.7 & 15.1 & 15.7 & 15.7 \\
\hline$T R D$ & 9.4 & 10.4 & 11.1 & 11.6 \\
\hline WTP & 5.5 & 7.8 & 8.7 & 9.7 \\
\hline$C M N$ & 0.8 & 1.0 & 1.1 & 1.3 \\
\hline Other Services & 19.7 & 20.8 & 22.4 & 23.4 \\
\hline OSG & 9.2 & 11.5 & 12.3 & 12.9 \\
\hline ROS & 4.7 & 2.9 & 3.0 & 3.1 \\
\hline$O B S$ & 4.3 & 5.0 & 5.5 & 5.7 \\
\hline OFI & 1.0 & 1.1 & 1.2 & 1.2 \\
\hline$I S R$ & 0.4 & 0.3 & 0.4 & 0.4 \\
\hline$D W E$ & 0.0 & 0.0 & 0.0 & 0.0 \\
\hline Light Manufacturing & 11.6 & 11.7 & 12.5 & 12.9 \\
\hline$P P P$ & 5.2 & 5.4 & 5.6 & 5.2 \\
\hline$F M P$ & 2.2 & 2.0 & 2.3 & 2.6 \\
\hline$M V H$ & 1.2 & 1.2 & 1.5 & 1.6 \\
\hline LUM & 1.2 & 1.2 & 1.0 & 1.1 \\
\hline$O M F$ & 1.0 & 1.1 & 1.2 & 1.4 \\
\hline OTN & 0.5 & 0.5 & 0.6 & 0.7 \\
\hline$L E A$ & 0.2 & 0.3 & 0.3 & 0.2 \\
\hline Extraction & 11.5 & 12.7 & 14.2 & 15.5 \\
\hline OIL & 4.5 & 4.2 & 4.3 & 4.3 \\
\hline GAS & 2.2 & 2.5 & 2.6 & 2.8 \\
\hline$O M N$ & 1.9 & 2.6 & 3.6 & 4.1 \\
\hline$F S H$ & 1.2 & 1.0 & 1.0 & 1.1 \\
\hline COA & 1.2 & 1.9 & 2.2 & 2.6 \\
\hline$F R S$ & 0.4 & 0.5 & 0.5 & 0.5 \\
\hline Processed Food & 4.6 & 5.4 & 5.5 & 5.9 \\
\hline$O F D$ & 2.3 & 2.8 & 2.8 & 3.1 \\
\hline
\end{tabular}




B_T
MIL
SGR
VOL
Grains and Crops
V_F
OCR
WHT
GRO
PCR
OSD
PFB
$P D R$
C_B
Textile and Wearing Apparel
TEX
WAP
Livestock and Meat Products
OAP
RMK
OMT
CTL
CMT
WOL

\begin{tabular}{|r|r|l|l|}
\hline 0.9 & 1.2 & 1.3 & 1.3 \\
\hline 0.5 & 0.8 & 0.8 & 0.9 \\
\hline 0.5 & 0.2 & 0.3 & 0.3 \\
\hline 0.3 & 0.3 & 0.3 & 0.4 \\
\hline 4.5 & $\mathbf{5 . 0}$ & 5.3 & 5.6 \\
\hline 1.4 & 1.6 & 1.7 & 1.7 \\
\hline 0.8 & 0.9 & 0.8 & 0.7 \\
\hline 0.6 & 0.6 & 0.7 & 0.8 \\
\hline 0.4 & 0.6 & 0.7 & 0.8 \\
\hline 0.3 & 0.1 & 0.2 & 0.2 \\
\hline 0.3 & 0.5 & 0.5 & 0.5 \\
\hline 0.3 & 0.3 & 0.3 & 0.3 \\
\hline 0.2 & 0.3 & 0.3 & 0.3 \\
\hline 0.1 & 0.1 & 0.1 & 0.2 \\
\hline 2.6 & 2.7 & 2.7 & 2.6 \\
\hline 2.1 & 1.9 & 2.0 & 1.9 \\
\hline 0.5 & 0.8 & 0.8 & 0.6 \\
\hline 2.5 & $\mathbf{2 . 1}$ & $\mathbf{2 . 2}$ & $\mathbf{2 . 3}$ \\
\hline 0.8 & 0.6 & 0.6 & 0.6 \\
\hline 0.4 & 0.3 & 0.3 & 0.4 \\
\hline 0.4 & 0.3 & 0.3 & 0.3 \\
\hline 0.4 & 0.4 & 0.3 & 0.4 \\
\hline 0.4 & 0.4 & 0.5 & 0.5 \\
\hline 0.0 & 0.1 & 0.1 & 0.1 \\
\hline & & & \\
\hline
\end{tabular}

Table A3: Sectoral annual energy use in Exajoules.

Country
China
Hong Kong
Japan
Korea
Mongolia
Taiwan
Rest of East Asia
Brunei Darassalam

Bahrain
Iran Islamic Republic of
Israel
Jordhan
Kuwait
Oman
Qatar
Saudi Arabia
Turkey

\section{Region \\ EastAsia \\ EastAsia \\ EastAsia \\ EastAsia \\ EastAsia \\ EastAsia \\ EastAsia \\ EastAsia}

MENA

MENA

MENA

MENA

MENA

MENA

MENA

MENA

MENA

\section{Country}

Austria

Belgium

Cyprus

Czech Republic

Denmark

Estonia

Finland

France

Germany

Greece

Hungary

Ireland

Italy

Latvia

Lithuania

Luxembourg

Malta

Netherlands

Poland
Region

EU_25

EU_25

EU_25

EU_25

EU_25

EU_25

EU_25

EU_25

EU_25

EU_25

EU_25

EU_25

EU_25

EU_25

EU_25

EU_25

EU_25

EU_25

EU_25 


\begin{tabular}{|c|c|c|}
\hline United Arab Emirates & MENA & Portugal \\
\hline Rest of Western Asia & MENA & Slovakia \\
\hline Egypt & MENA & Slovenia \\
\hline Morocco & MENA & Spain \\
\hline Tunisia & MENA & Sweden \\
\hline Rest of North Africa & MENA & United Kingdom \\
\hline Benin & SSA & Australia \\
\hline Burkina Faso & SSA & New Zealand \\
\hline Cameroon & SSA & Rest of Oceania \\
\hline Cote d'Ivoire & SSA & \\
\hline Ghana & SSA & Cambodia \\
\hline Guinea & SSA & Indonesia \\
\hline Nigeria & SSA & Lao People's Democratic Republ \\
\hline Senegal & SSA & Malaysia \\
\hline Togo & SSA & Philippines \\
\hline Rest of Western Africa & SSA & Singapore \\
\hline Central Africa & SSA & Thailand \\
\hline South Central Africa & SSA & Viet Nam \\
\hline Ethiopia & SSA & Rest of Southeast Asia \\
\hline Kenya & SSA & \\
\hline Madagascar & SSA & Canada \\
\hline Malawi & SSA & United States of America \\
\hline Mauritius & SSA & Mexico \\
\hline Mozambique & SSA & Rest of North America \\
\hline Rwanda & SSA & \\
\hline Tanzania & SSA & Bangladesh \\
\hline Uganda & SSA & India \\
\hline Zambia & SSA & Nepal \\
\hline Zimbabwe & SSA & Pakistan \\
\hline Rest of Eastern Africa & SSA & Sri Lanka \\
\hline Botswana & SSA & Rest of South Asia \\
\hline Namibia & SSA & \\
\hline South Africa & SSA & \\
\hline Rest of South African Customs & SSA & \\
\hline Argentina & LatinAmer & Switzerland \\
\hline Bolivia & LatinAmer & Norway \\
\hline Brazil & LatinAmer & Rest of EFTA \\
\hline Chile & LatinAmer & Albania \\
\hline Colombia & LatinAmer & Bulgaria \\
\hline Ecuador & LatinAmer & Belarus \\
\hline Paraguay & LatinAmer & Croatia \\
\hline Peru & LatinAmer & Romania \\
\hline
\end{tabular}

EU_25

EU_25

EU_25

EU_25

EU_25

EU_25

Oceania

Oceania

Oceania

SEAsia

SEAsia

SEAsia

SEAsia

SEAsia

SEAsia

SEAsia

SEAsia

SEAsia

NAmerica

NAmerica

NAmerica

NAmerica

SouthAsia

SouthAsia

SouthAsia

SouthAsia

SouthAsia

SouthAsia

RestofWorld RestofWorld RestofWorld RestofWorld RestofWorld RestofWorld RestofWorld RestofWorld 


$\begin{array}{lll}\text { Uruguay } & \text { LatinAmer } & \text { Russian Federation } \\ \text { Venezuela } & \text { LatinAmer } & \text { Ukraine } \\ \text { Rest of South America } & \text { LatinAmer } & \text { Rest of Eastern Europe } \\ \text { Costa Rica } & \text { LatinAmer } & \text { Rest of Europe } \\ \text { Guatemala } & \text { LatinAmer } & \text { Kazakhstan } \\ \text { Honduras } & \text { LatinAmer } & \text { Kyrgyztan } \\ \text { Nicaragua } & \text { LatinAmer } & \text { Rest of Former Soviet Union } \\ \text { Panama } & \text { LatinAmer } & \text { Armenia } \\ \text { El Salvador } & \text { LatinAmer } & \text { Azerbaijan } \\ \text { Rest of Central America } & \text { LatinAmer } & \text { Georgia } \\ \text { Dominican Republic } & \text { LatinAmer } & \text { Rest of the World } \\ \text { Jamaica } & \text { LatinAmer } & \\ \text { Puerto Rico } & \text { LatinAmer } & \\ \text { Trinidad and Tobago } & \text { LatinAmer } & \\ \text { Caribbean } & \text { LatinAmer } & \end{array}$

RestofWorld

RestofWorld

RestofWorld

RestofWorld

RestofWorld

RestofWorld

RestofWorld

RestofWorld

RestofWorld

RestofWorld

RestofWorld

Table A4: Overview of countries and regions used. 